\title{
Assessment of Concentration levels of contaminants in groundwater of Soutpansberg Region, Limpopo Province, South Africa
}

Lindelani Lalumbe ( $\square$ lindelanilalumbe@ymail.com )

Department of Water Affairs and Forestry: South Africa Department of Water and Sanitation https://orcid.org/0000-0001-7842-205X

Thokozani Kanyerere

University of the Western Cape

\section{Research Article}

Keywords: Contaminants, Groundwater quality, Parachute research, Sustainable Development Goals.

Posted Date: June 7th, 2021

DOl: https://doi.org/10.21203/rs.3.rs-476038/v1

License: (c) (1) This work is licensed under a Creative Commons Attribution 4.0 International License. Read Full License

Version of Record: A version of this preprint was published at Water on April 21st, 2022. See the published version at https://doi.org/10.3390/w14091354. 


\section{Abstract}

Groundwater contribution towards improved food security and human health depend on the level of contaminants in groundwater. In rural areas, many people use groundwater for drinking and irrigation purposes without treatment and have no knowledge of contaminants levels in such waters. The reason for such lack of treatment and knowledge is due to the parachute type of research which emphasizes on scientific knowledge and records only and not sharing research outputs with communities for improved human health and food security. This study argued that parachute research type exposes groundwater users to health hazards and threaten food security. Concentration levels of contaminants were measured to ascertain suitability of groundwater for drinking and irrigation use. 124 groundwater quality samples from 12 boreholes and 2 springs with physiochemical data from 1995 to 2017 were assessed. This study found high concentration levels of contaminants such $\mathrm{F}^{-}, \mathrm{NO}_{3}{ }^{-}, \mathrm{Cl}^{-}$and TDS in certain parts of the studied area when compared to water quality standards. In general, groundwater was deemed suitable for drinking purposes in most part of the studied area. Combined calculated values of SAR, $\mathrm{Na} \%, \mathrm{MH}, \mathrm{PI}, \mathrm{RSC}$ and TDS determined that groundwater is suitable for irrigation purposes. The discussion in this paper showed that scientific knowledge generated on groundwater quality should be shared with water users as it will improved human health and food security and also enhance the achievement of Sustainable Development Goals. This study recommended that skills and research outputs should be shared with groundwater users through various initiatives.

\section{Introduction}

Availability of water in general is declining owing to climatic variation such as drought in arid and semiarid regions and increasing demand owing to socio-economic activities. Groundwater has become the main or only source of freshwater for various activities such as irrigation and domestic uses across the world $(38,27,53,20)$, and this is especially common in rural areas where there is lack or no alternative water supply. Increasing reliance on groundwater can lead to other ecological factors such as decreasing groundwater level, pollution and deterioration of water quality (24). Globally it is being reported that groundwater that was considered fresh is increasingly being contaminated or polluted and this can have a negative impact on the livelihood of vulnerable people relying on groundwater for various uses $(43,2)$. There are various components that influence groundwater quality and determine the concentration levels of contaminants in rural areas. These components include anthropogenic activities (irrigation and pitlatrines), leaching, regional geology as well as climatic conditions $(32,26,22,52)$. For groundwater to contribute towards food security and improved rural livelihood through irrigation and domestic use, concentration levels of contaminants should be determine to ensure groundwater is suitable for various uses. The challenge is that majority of groundwater users in many rural areas uses groundwater without treatment or knowledge of the concentration level of contaminants; a situation which poses a huge threat to food security, human health and their livelihoods. Understanding and communicating the concentration levels of contaminants and groundwater quality in general is important as it ensure that people use groundwater that is safe for consumption (36). Various researchers $(29,46,28,9,31)$ 
assessed groundwater quality data across the world to determine the suitability of groundwater for human consumption. They evaluated major cations $\left(\mathrm{Ca}^{2+}, \mathrm{Mg}^{2+}, \mathrm{Na}^{+}, \mathrm{K}^{+}\right)$and anions $\left(\mathrm{Cl}^{-}, \mathrm{HCO}_{3}{ }^{-}, \mathrm{F}^{-}\right)$. These studies compared groundwater quality data with drinking water standards such as (51) and various local standards such as (40) in South Africa. Suitability of groundwater for irrigation contributes towards food security (17). Groundwater that is not suitable for irrigation may reduce crop yield and damage soil structure (3). Studies conducted by $(40,28,10,35,1,16)$ assessed the suitability of groundwater for irrigation purposes using methods such as SAR, PI, RSC, $\mathrm{Na} \%$ and $\mathrm{MH}$ and found contrasting results from methods applied. Contaminants are input of foreign and possibly toxic materials into the environment and pollutants are described as substances that are anthropogenically introduced that may be harmful to the environment (44). It is not simple to distinguish between contaminants and pollutants as it is not always possible to define the concentration level where contaminants become pollutants (44). However, it has become a norm with various authors to compare concentration levels of contaminants in groundwater to various standards that are largely for surface water or drinking water in order to determine if contaminants in groundwater are pollutants. This practice may be misleading as some aquifers are highly concentrated in some contaminants in nature and not polluted; this study tapped in the subject of comparing contaminants in groundwater to various international and local standards. The purpose of this study was to determine the concentration levels of contaminants, spatial distribution of contaminants and evaluate suitability of groundwater for domestic and irrigation purposes using long-term data. This study also discussed the parachute type of research that does not share the outputs and skills on groundwater quality with affected communities.

\section{Description Of Study Location}

The Soutpansberg region is located in the far Northern part of the Limpopo Province in South Africa (Fig. 1). The total area of region is about $3099.6 \mathrm{~km} 2$ and lies between 250 to 1719 meters above mean seal level. There are 12 boreholes and 2 springs that are part of the groundwater quality monitoring programme in the area. In terms of groundwater level, 19 groundwater monitoring boreholes indicated that groundwater level ranged from 1.5 to 36 meters below groundwater level. There are 994 registered groundwater users with an allocation of $148.3 \mathrm{Mm} 3 / \mathrm{a}$ for various uses in the area. Although the study focuses on groundwater, other main waterbodies includes rivers such as Sandsloot and Mutamba which are located in the western side of the Soutpansberg region. In the central part there are rivers such as Mutshedzi, Nzhelele and Nwanedi. Mutshindudi, Luvuvhu, Mutale, Mbodi and Shisha rivers are located in the eastern side of the Soutpansberg region. There are also several dams in the Soutpansberg region such as Nzhelele, Nwanedi, Mutshedzi and Vondo. Soutpansberg region covers Towns such as Louis Trichardt, Makhado and Thohoyandou (Fig. 1). In terms of land cover in the Soutpansberg region, 27.5\% of the area is covered by woodlands, cultivated land covers about $25.5 \%, 25.3 \%$ is covered by bushland, $13 \%$ is covered with forest plantation, $7.4 \%$ is covered by residential/ built up area, water bodies covers $0.9 \%$ and $0.4 \%$ is covered by natural rocks and soils. 
In terms of climatic condition, the area is located in an arid region with average minimum temperature of $11 \circ \mathrm{C}$ and average maximum temperature of $32 \circ \mathrm{C}$ based of the 7 South African Weather Services (SAWS) station with data from 1980 to 2020. Soutpansberg region experience dry winter season (May- August) and wet summer season (December- February) with the average precipitation of $497.7 \mathrm{~mm} / \mathrm{a}$. The dominant geology that support groundwater is the volcanic-sedimentary unit of Soutpansberg Group deposited as an east-west gravitating asymmetrical rift beside the palala shear belt about 1800 million years ago $(7,8)$. The Soutpansberg basin was formed between the Limpopo belt in the north and the Kaapvaal craton in the south. This volcanic-sedimentary Soutpansberg Group mainly outcrops in the Soutpansberg Mountains stretching from Punda Maria at the eastern side to Vivo at the western side (11, 5). The Soutpansberg Group is subdivided into five Formations (Fig. 2) which are Tshifhefhe, Sibasa, Fundudzi, Wyllie's Poort and Nzhelele Formations (4). The dominant aquifer type in the Soutpansberg region is the fractured aquifer with an average borehole yield ranging between 0 and $0.5 \mathrm{l} / \mathrm{s}$. Some small part of this fractured aquifer average borehole yield can reach $2 \mathrm{l} / \mathrm{s}$. The southern part of the Soutpansberg is underlain by the intergranular and fractured aquifer with average borehole yield between 0 and $0.2 \mathrm{l} / \mathrm{s}$.

\section{Material And Methods \\ 3.1. Sampling}

There is an active groundwater quality monitoring network in the study area. The network is comprised of 12 boreholes and 2 geothermal springs where sampling has been taking place since 1995 twice a year (wet and dry seasons). The monitoring network was designed to monitor any influence on groundwater resources in the Soutpansberg region. The monitoring points are spatially distributed in the Soutpansberg region. To evaluate the concentration level of contaminants in groundwater, 124 samples of physiochemical parameters were analysed. These parameters include Magnesium $\left(\mathrm{Mg}^{2+}\right)$, Calcium $\left(\mathrm{Ca}^{2+}\right)$, Sodium $\left(\mathrm{Na}^{+}\right)$, Potassium $\left(\mathrm{K}^{+}\right)$, Bicarbonate $\left(\mathrm{HCO}_{3}{ }^{-}\right)$, Chloride $\left(\mathrm{Cl}^{-}\right)$, Nitrate $\left(\mathrm{NO}_{3}{ }^{-}\right)$and Fluoride $\left(\mathrm{F}^{-}\right)$.Total dissolved solids (TDS) was calculated based on in-situ measurement of electrical conductivity (EC) using Eq. 1 (48). In-situ measurements of $\mathrm{pH}$ and temperature were taken at each sampling point using a handheld multi-parameter probe. Groundwater samples were collected using (48) methods where samples were collected after purging the borehole until electrical conductivity (EC), $\mathrm{pH}$, and Temperature stabilized. Purging of the borehole is important as it allows a representation sample of the aquifer to be collected. Groundwater from the spring was collected directly from the eye of the spring. $500 \mathrm{ml}$ polyethylene sampling bottles were used to collect groundwater. The samples between 1995 and 2017 (124 samples) were analysed at Department of Water and Sanitation laboratory using Inductively Coupled Plasma Mass Spectrometry (ICP-MS) and the results were available as record review from the Department of Water and Sanitation's Water Management System database. To ensure that there are no uncertainties with the data, ion balance error was determined to be between 0.0 and $9 \%$ which is lower than allowable range of $10 \%(49)$. 
$\mathrm{TDS}=6.3 * \mathrm{EC}\left(\frac{\mathrm{mS}}{\mathrm{m}}\right)$

\subsection{Determination of concentration levels of contaminants}

The analysed 124 samples of major ions and physical parameters were statistically assessed using Microsoft Excel in order to determine the concentration levels of contaminants in the Soutpansberg region. The statistical analyses tool was used to determine the mean, minimum, maximum and standard deviation of various contaminants. ArcGis tool was used to map the spatial distribution of the concentration levels of contaminants. The determined concentration levels of contaminants in groundwater were used to discuss the subject of comparing ambient groundwater quality to various standards and sharing of outputs with concerned communities.

\subsection{Evaluation of groundwater quality for domestic and irrigation purposes}

To evaluate suitability of groundwater for domestic use in the Soutpansberg region, 124 samples of major ions and physical parameters were compared to $(51,40)$ drinking water standards. Suitability of groundwater for irrigation purpose was evaluated by using equations 2- 6 below. Sodium adsorption ratio (SAR), sodium percentage ( $\mathrm{Na} \%)$, permeability index (PI), residual sodium carbonate (RSC) and magnesium hazard $(\mathrm{MH})$ were calculated in meq/l from the 124 samples. The subject of parachute research and sharing of knowledge with groundwater users was discussed based on the outcome of these methods.

$\mathrm{SAR}=\left(\mathrm{Na}^{+}\right) /\left[\sqrt{ }\left(\mathrm{Ca}^{2+}+\mathrm{Mg}^{2+}\right) / 2\right]$

$\mathrm{Na} \%=\left[\left(\mathrm{Na}^{+}+\mathrm{K}^{+}\right) /\left(\mathrm{Ca}^{2+}+\mathrm{Mg}^{2+}+\mathrm{Na}^{+}+\mathrm{K}^{+}\right)\right]^{\star} 100$

$\mathrm{PI}=\left[\left(\mathrm{Na}^{+}+\mathrm{HCO}_{3}{ }^{-}\right) /\left(\mathrm{Ca}^{2+}+\mathrm{Mg}^{2+}+\mathrm{Na}^{+}\right)\right] * 100$

$\mathrm{RSC}=\left(\mathrm{CO}_{3}^{2-}+\mathrm{HCO}_{3}^{-}\right)-\left(\mathrm{Ca}^{2+}+\mathrm{Mg}^{2+}\right)$

$\mathrm{MH}=\left(\mathrm{Mg}^{2+} \times 100\right) /\left(\mathrm{Ca}^{2+}+\mathrm{Mg}^{2+}\right)$

\section{Results And Discussion}

\subsection{Chemical composition of groundwater}

The descriptive statistical analysis of chemical constituents of the 124 samples of the Soutpansberg region is presented in Table 1. It is commonly accepted that $\mathrm{pH}$ is the primary parameter that is used to measure water quality if it is acidic $(\mathrm{pH}<7)$, Neutral $(\mathrm{pH}=7)$ or alkaline $(\mathrm{pH}>7)$ in nature (25).

Groundwater in the Soutpansberg region is slightly acidic to alkaline as $\mathrm{pH}$ ranges from 6.7 to 9.6. The mean $\mathrm{pH}$ in groundwater of the area is 8.4 which indicate that groundwater is more alkaline (Table 1). High alkalinity in the Soutpansberg area is linked with high concentrations of sodium, magnesium, 
calcium and bicarbonates ions owing to the mafic-ultramafic igneous rocks dominant in the area. These ions are commonly known to increase the value of $\mathrm{pH}(13)$. In terms of seasonal variation, there is no much difference in $\mathrm{pH}$ between dry and wet season in the Soutpansberg region.

Table 1

Descriptive statistical analysis of physiochemical parameters

\begin{tabular}{|lllllllllll|}
\hline & $\mathbf{p H}$ & TDS & $\mathrm{Ca}^{2+}$ & $\mathbf{M g}^{2+}$ & $\mathrm{Na}^{+}$ & $\mathrm{K}^{+}$ & $\mathrm{Cl}^{-}$ & $\mathrm{HCO}_{3}^{--}$ & $\mathbf{N O}_{3}^{-}$ & $\mathbf{F}^{-}$ \\
\hline Wet Season N=29 & & & & & & & & & & \\
\hline Min & 6,7 & 32 & 1 & 1 & 3 & 0,2 & 5 & 6 & 0,01 & 0,03 \\
\hline Max & 9,4 & 1723 & 83 & 137 & 460 & 10 & 755 & 455 & 18,8 & 2,8 \\
\hline Mean & 8,4 & 378 & 19 & 20 & 76 & 2 & 99 & 141 & 2,5 & 0,8 \\
\hline SD & 1,4 & 969 & 43 & 74 & 246 & 5 & 408 & 231 & 10,2 & 1,4 \\
\hline Dry Season N=95 & & & & & & & & & & \\
\hline Min & 7,1 & 82 & 1 & 1 & 3 & 1 & 7 & 5 & 0,01 & 0,03 \\
\hline Max & 9,6 & 1808 & 99 & 154 & 415 & 10 & 646 & 612 & 37 & 2.9 \\
\hline Mean & 8,4 & 372 & 23 & 24 & 61 & 2 & 68 & 178 & 4 & 0.7 \\
\hline SD & 1,3 & 941 & 51 & 83 & 223 & 5 & 352 & 313 & 20 & 1.5 \\
\hline All Season N= 124 & & & & & & & & & & \\
\hline Mean & 8.4 & 372 & 22 & 23 & 65 & 2 & 75 & 170 & 4 & 0.7 \\
\hline WHO (2011) & $6,5-8,5$ & 1000 & 200 & 100 & 200 & 12 & 250 & 500 & 10 & \\
\hline SANS 241 (2015) & $5-9,7$ & 1200 & 150 & 70 & 200 & 50 & 300 & & 11 & 1,5 \\
\hline *All units expressed in mg/l except pH; SD: standard deviation & & & & \\
\hline
\end{tabular}

Salinity as TDS in the region ranged from 32 to $1808 \mathrm{mg} / \mathrm{l}$ with mean of $327 \mathrm{mg} / \mathrm{l}$. Spatial distribution of TDS is presented in Fig. 3 where mean concentrations of 1418 and $1784 \mathrm{mg} / \mathrm{l}$ at Maebane and Punda Maria villages were recorded respectively. Groundwater in these areas is considered to be brackish according to TDS classification in Table 2 (18). There is a strong correlation between the spatial distributions of $\mathrm{Cl}^{-}$and TDS (Fig. 3-4) in the Soutpansberg region and this suggest that salinity in groundwater is high in the Maebane and Punda Maria villages as groundwater is classified as brackish. There is a correlation between salinity and human settlements (including irrigated area) in the Soutpansberg region and this observation is common as activities in such areas are associated various types of anthropogenic factors such as fertilizers and pit-latrines. (34) Found that spatial variation of groundwater quality correlate with agricultural activities. Seasonal variation does not affect salinity in the area as there is no difference between wet $(378 \mathrm{mg} / \mathrm{l})$ and dry $(372 \mathrm{mg} / \mathrm{l})$ season mean TDS. In general, $91.1 \%$ of groundwater is the Soutpansberg region is classified as fresh and $8.9 \%$ is classified as brackish 
(Table 2). Classification of groundwater for TDS in this study is similar to (28) who determined that groundwater in the Soutpansberg region is fresh to brackish.

Table 2

Classification of groundwater based on TDS (18)

\begin{tabular}{|lll|}
\hline Classification & TDS $(\mathrm{mg} / \mathrm{l})$ range & No. of samples (\%) \\
\hline Fresh & $<1000$ & $113(91.1 \%)$ \\
\hline Brackish & $1000-10,000$ & $11(8.9 \%)$ \\
Saline & $10,000-100,000$ & 0 \\
Brine & $>100,000$ & 0 \\
\hline
\end{tabular}

The concentration levels of various contaminants are presented in Table 1, where cation dominance order was $\mathrm{Na}^{+}>\mathrm{Mg}^{2+}>\mathrm{Ca}^{2+}>\mathrm{K}^{+}$and anions was $\mathrm{HCO}_{3}{ }^{-}>\mathrm{Cl}^{-}>\mathrm{NO}_{3}{ }^{-}>\mathrm{F}^{-} . \mathrm{HCO}_{3}{ }^{-}$concentration in groundwater ranged from 5 to $612 \mathrm{mg} / \mathrm{l}$ with mean of $170 \mathrm{mg} / \mathrm{l}$. in terms of seasonal variation, mean $\mathrm{HCO}_{3}{ }^{-}$concentration of 141 and $178 \mathrm{mg} / \mathrm{l}$ were recorded in wet and dry seasons respectively indicating that seasonal variation impact is minimal. Majority of samples and mean concentration of $\mathrm{HCO}_{3}{ }^{-}$is within the $(51,40)$ standards (in the absence of groundwater quality standards). Concentration levels of $\mathrm{Cl}^{-}$ranged from 5 to $755 \mathrm{mg} / \mathrm{l}$ with mean of $75 \mathrm{mg} / \mathrm{l}$. Spatial distribution of mean $\mathrm{Cl}^{-}$concentration in groundwater of the Soutpansberg region indicate that it is highly concentrated where TDS concentrations are high (Fig. 4). Mean concentration of $\mathrm{Cl}^{-}$in groundwater is slightly higher in the wet season (99 mg/l) compared to dry season $(68 \mathrm{mg} / \mathrm{l}) . \mathrm{NO}_{3}{ }^{-}$concentration levels in groundwater of the area ranged between 0.01 and $37 \mathrm{mg} / \mathrm{l}$ with mean of $4 \mathrm{mg} / \mathrm{l} . \mathrm{NO}_{3}{ }^{-}$is highly concentrated in villages such as Maebane (22.3 $\mathrm{mg} / \mathrm{l})$, Gogogo (15 mg/l) and Tshitavha Sambandou (15 mg/l) as presented in Fig. 5. A study by (1) found that $\mathrm{NO}_{3}{ }^{-}$was 8.8 times than the recommended limit and stated $\mathrm{NO}_{3}{ }^{-}$occurrence and distribution in groundwater is mostly associated with application of fertilizers, leakage from septic tanks/ sewage and leachate from landfill sites. In the Soutpansberg area, high $\mathrm{NO}_{3}{ }^{-}$can be associated with leaching from pit-latrines and application of fertilizers in this fractured aquifer. There is no major difference in mean $\mathrm{NO}_{3}{ }^{-}$concentration in groundwater between wet $(2.5 \mathrm{mg} / \mathrm{l})$ and dry $(4 \mathrm{mg} / \mathrm{l})$ seasons. $\mathrm{NO}_{3}{ }^{-}$ concentration is slightly higher in dry season as compared to wet season. Spatial distribution of $\mathrm{F}^{-}$is presented in Fig. 6 where it is highly concentrated around Nzhelele area with a mean of $2.5 \mathrm{mg} / \mathrm{l}$. The mean concentration level of $\mathrm{F}^{-}$in Nzhelele area is over the prescribed limit of $1.5 \mathrm{mg} / \mathrm{l}(51,40)$. Groundwater from the geothermal spring in Nzhelele is highly concentrated with $\mathrm{F}^{-}$. The range of $\mathrm{F}^{-}$ concentration levels in groundwater of the Soutpansberg region was determined to be from 0.03 to 2.9 $\mathrm{mg} / \mathrm{l}$ and overall mean of $0.7 \mathrm{mg} / \mathrm{l}$. Seasonal variation doesn't have any impact on $\mathrm{F}^{-}$concentration of groundwater as geothermal springs are associated with deep ancient groundwater. The determined concentration of $\mathrm{F}^{-}$correlates with the findings of (33) that $\mathrm{F}^{-}$in Nzhelele (Siloam) area ranges between 1.7 to $5.6 \mathrm{mg} / \mathrm{l}$ in dry and wet seasons. The source of $\mathrm{F}^{-}$in groundwater in this area result from fluorite mineral associated with sedimentary and igneous rocks that are found in the Soutpansberg area (33). 
In the absence of defined groundwater quality guidelines, majority of samples contains cations concentration levels that are within the $(51,40)$ prescribed limits for drinking water. High concentration levels of various parameters does not necessary mean the aquifer is polluted as it could be the natural ambient groundwater. Mean wet and dry season's concentration levels of cations are below the prescribed limit (Table 1). Cations concentrations level in groundwater of the Soutpansberg region are not influenced or affected by seasonal variations as there is no major difference in concentration levels between wet and dry season samples. Concentration level of $\mathrm{Na}^{+}$being the dominant cation ranged from 3 to $440 \mathrm{mg} / \mathrm{l}$ with mean concentration of $65 \mathrm{mg} / \mathrm{l}$. Na ${ }^{+}$concentration is slightly higher in wet season (76 $\mathrm{mg} / \mathrm{l})$ than dry season $(61 \mathrm{mg} / \mathrm{l}) . \mathrm{Na}^{+}$is highly concentrated in Maebane and Punda Maria where concentrations of TDS and $\mathrm{Cl}^{-}$are high. Salinity in groundwater seems to be a problem in these areas due to high concentration of TDS, $\mathrm{Cl}^{-}$and $\mathrm{Na}^{+}$. Salinity in Maebane and Punda Maria settlements is high in all seasons. $\mathrm{Mg}^{2+}$ concentration levels in groundwater ranged from 1 to $154 \mathrm{mg} / \mathrm{l}$ with mean of 23 $\mathrm{mg} / \mathrm{l}$. The spatial distribution of $\mathrm{Mg}^{2+}$ concentration in groundwater is presented on Fig. 7 where it is highly concentrated in the Maebane and Gogogo villages. Mean $\mathrm{Mg}^{2+}$ concentration levels of 77 and 118 $\mathrm{mg} / \mathrm{l}$ were determined in Gogogo and Maebane villages respectively and these concentration levels are above the prescribed limit of $70 \mathrm{mg} / \mathrm{l}(51,40)$. Concentration levels of $\mathrm{Ca}^{2+}$ in groundwater of the Soutpansberg region ranged from 1 to $99 \mathrm{mg} / \mathrm{l}$ with mean of $22 \mathrm{mg} / \mathrm{l}$. in terms of seasonal variation, mean $\mathrm{Ca}^{2+}$ concentration level of 19 and $23 \mathrm{mg} / \mathrm{l}$ were recorded in wet and dry seasons respectively. Concentration levels of $\mathrm{K}^{+}$as the least dominance cation ranged from 0.2 to $10 \mathrm{mg} / \mathrm{l}$ with mean of 2 $\mathrm{mg} / \mathrm{l}$, which is within the prescribed limit $(51,40)$. Comparing ambient groundwater with standards designed largely for surface and treated water such as (40) can be misleading as it may be perceived as groundwater resource is polluted. For instance, TDS in Maebane area has been over $1500 \mathrm{mg} / \mathrm{l}$ since 1994 and steady at that concentration level for over 22 years. Some contaminants in groundwater are naturally high owing to the geochemistry and geological setting of the host aquifer so there is need to develop groundwater quality standards guided by historical data and geochemistry of aquifers. In cases where anthropogenic activities are determined to be contaminating groundwater resource, sharing of concentration levels of contaminants and research outcomes can assist the community to manage and protect the resource. Enhanced management and protection of groundwater resource between communities and custodian of the resource will help countries to achieve United Nation's Sustainable Development Goal (SDG) 6 and this will improve water quality and provide clean water and sanitation for all.

\subsection{Suitability of groundwater for drinking purposes}

Groundwater should be free from pathogens and toxic chemicals in order to be deemed suitable for domestic use such as cooking and drinking (28). Concentrations of various parameters from the 124 samples were compared with $(51,40)$ in Table 1 . These samples were also compared to TDS classifications by (18) in Table 2 and (12) in Table 3. In terms of seasonal variations, $62.1 \%$ of wet season samples were suitable for drinking purposes. $74.7 \%$ of samples taken in dry season were suitable for drinking purposes in the Soutpansberg area. Even though there is no major difference in concentration 
levels, groundwater seems to be more suitable for drinking purposes in dry season. This could be associated with lack of mechanism to enhance leaching/ transport contaminants in dry season. Overall, groundwater in $73.4 \%$ of the samples was deemed suitable for drinking purposed as all parameters were within the prescribed limit $(51,40)$. This outcome is in contrast with (28) study that determined that groundwater in the Soutpansberg is not suitable for drinking and domestic purposes. However, the contrast can be associated with the spatial distribution of monitored samples, number of samples and time frame as (28) analysed 15 samples in 2011 from a small portion of the Soutpansberg, and 124 spatial distributed samples were used in this study with data of 22 years. According to Department of Water and Sanitation Water Authorization and Registration Management System (WARMS), 3.7 Mm3/a of groundwater has been allocated for drinking purposes in the Soutpansberg region. This can become a challenge as groundwater in $26.6 \%$ (37.9\% and $25.3 \%$ in wet and dry seasons respectively) of the samples were deemed not suitable for drinking purposes due to high concentrations of $\mathrm{F}^{-}, \mathrm{NO}_{3}{ }^{-}, \mathrm{Mg}^{2+}$ and salinity (TDS and $\mathrm{Cl}^{-}$) in areas such as Maebane, Punda Maria, Tshitavha Sambandou, Gogogo, Nzhelele and surrounding villages as presented in Fig. 3-7. These contaminants are high in boreholes/springs in residential settlements and irrigated areas. Majority of groundwater users in the Soutpansberg region are most likely not aware of the type of groundwater they are drinking on a daily basis. It is basic human rights and need to drink safe water to ensure good health (23). (50) Estimated that almost $80 \%$ of diseases are resulting from polluted water and poor sanitation and this could be the case in the rural villages of the Soutpansberg region due to continuous consumption of polluted groundwater. For instance, concentration of TDS in Punda Maria (ZQMPMA1) and Maebane (ZQMMBI1) areas were recorded at $1784 \mathrm{mg} / \mathrm{l}$ and $1418 \mathrm{mg} / \mathrm{l}$ respectively and water with elevated dissolved solids may affect individual suffering from heart and kidney diseases as well as causing constipation and laxative effects (41). NO3- as one of the common disease causing contaminants can expose infants to baby blue syndrome $(51,30) . \mathrm{F}^{-}$which is highly concentrated in Nzhelele area (Siloam) can cause dental fluorosis according to (51). A study by (33) found that of the $87 \%$ households that use groundwater for drinking purposes, $85 \%$ of the members already have mottled teeth/ dental fluorosis. Based on TDS classification by (18), $91.1 \%$ of the samples were classified as fresh water type and $8.9 \%$ of the samples were classified as brackish (Table 2). Classification of TDS by (12) indicated that $72.6 \%$ of groundwater samples were desirable for drinking purpose. $18.5 \%$ of groundwater samples in the Soutpansberg region were permissible for drinking purposes. Only $8.9 \%$ of the samples were not suitable for drinking purposes (Table 3). The main challenge is how the status of groundwater with respect to suitability for drinking purposes can be shared with groundwater users. Communicating with users that groundwater is not suitable for drinking purposes without treatment will protect them from possible water borne diseases, improving their health and livelihood. For instance, rainfall and temperature are forecasted by weather services globally as an early warning system and shared on various digital and print media. Perhaps groundwater custodians should start sharing groundwater quality status with groundwater users through various digital and print platforms and also with traditional authorities in rural areas. Sharing of groundwater quality status with communities relying on groundwater for drinking purposes will improve their health and livelihood as proper actions can be taken before consumption. Sharing the reasons why groundwater is not suitable for drinking purposes with water users will decrease water-borne diseases 
around the world as users will be aware. The situation discussed by (33) where $85 \%$ of groundwater users had dental fluorosis in Siloam can be avoided by sharing research outcome with users while also accelerating the achievement of SDG 3 dealing with good health and well-being.

Table 3

Groundwater classification based on TDS (12)

\begin{tabular}{|l|lll|}
\hline \multicolumn{1}{|l|}{ TDS (mg/l) } & Classification & No. of samples (\%) \\
\hline$<\mathbf{5 0 0}$ & Desirable for drinking & $90(72.6 \%)$ \\
\hline $\mathbf{5 0 0 - 1 0 0 0}$ & Permissible for drinking & $23(18.5 \%)$ \\
\hline $\mathbf{1 0 0 0 - 3 0 0 0}$ & Useful for irrigation & $11(8.9 \%)$ \\
\hline$>\mathbf{3 0 0 0}$ & Unfit for drinking and irrigation & 0 \\
\hline
\end{tabular}

High concentration of salt in irrigation water can increase solution osmotic pressure and can also negatively affect the structure of soils, aeration and permeability rate $(47,21)$. Suitability of groundwater of the Soutpansberg region for irrigation was assessed by estimating a number of parameters such as $\mathrm{Na} \%, \mathrm{SAR}, \mathrm{MH}, \mathrm{PI}, \mathrm{RSC}$ (Table 4) and TDS (Table 3). The major ions used were expressed in milliequivalents per litre $(\mathrm{meq} / \mathrm{l})$. 
Table 4

Classification of groundwater samples for suitability for irrigation

\begin{tabular}{|c|c|c|c|c|}
\hline Parameter & Range & Water class & No. of samples & (\%) \\
\hline \multirow[t]{5}{*}{$\mathrm{Na} \%$} & $<20$ & Excellent & 4 & 3,2 \\
\hline & $20-40$ & Good & 42 & 33,9 \\
\hline & $40-60$ & Permissible & 43 & 34,7 \\
\hline & $60-80$ & Doubtful & 6 & 4,8 \\
\hline & $>80$ & Unsuitable & 29 & 23,4 \\
\hline \multirow[t]{4}{*}{ SAR (meq/l) } & $<2$ & Excellent & 57 & 46 \\
\hline & $2-8$ & Good & 36 & 29 \\
\hline & $8-15$ & Doubtful & 30 & 24,2 \\
\hline & $>15$ & Unsuitable & 1 & 0,8 \\
\hline \multirow[t]{2}{*}{ MH (\%) } & $<50$ & Suitable & 30 & 24,2 \\
\hline & $>50$ & Unsuitable & 94 & 75,8 \\
\hline \multirow[t]{3}{*}{ PI (\%) } & Class I (> 75) & Good & 3 & 2.4 \\
\hline & Class II $(75-50)$ & Permissible & 106 & 85.5 \\
\hline & Class III $(<25)$ & Unsuitable & 15 & 12.1 \\
\hline \multirow[t]{2}{*}{ RSC (meq/l) } & $<2,5$ & Suitable & 124 & 100 \\
\hline & $>2,5$ & Unsuitable & 0 & 0 \\
\hline
\end{tabular}

\subsubsection{Alkali and salinity hazard (SAR)}

Sodium adsorption ration (SAR) is useful in determining suitability of groundwater for irrigation purpose as it measures both sodium and alkali hazards for plants (3). High concentration of sodium in irrigation water may have harmful effects in most soils such as increased hardness and reduced permeability (6). High concentration of bicarbonate and relatively low calcium is also hazardous for irrigation water (39). High content of sodium relative to calcium and magnesium may cause sodicity in irrigation water. SAR calculations (Eq. 2) in the Soutpansberg region indicated that $75 \%$ of the samples were classified as excellent -good for irrigation purposes (Table 4). $24.2 \%$ of the samples were doubtful and $0.8 \%$ of the samples were unsuitable for irrigation purposes. Groundwater from Tshipise (geothermal spring) and Punda Maria were doubtful for irrigation purposes as presented in Fig. 8. Samples that are unsuitable for irrigation purposes $(0.8 \%)$ are from Tshipise geothermal spring (ZQMTPS2) where the low mean concentrations of $\mathrm{Ca}^{2+}(2 \mathrm{mg} / \mathrm{l})$ and $\mathrm{Mg}^{2+}$ in relation to $\mathrm{Na}^{+}(66 \mathrm{mg} / \mathrm{l})$ are responsible for the unsuitability of groundwater for irrigation purpose as low calcium is hazardous for irrigation (39). Similar to suitability of drinking status, the communities and farmers that are using groundwater for irrigation purposes are 
deprived of this information as most researchers and custodians of water are publishing research outputs and not share with communities affected and this can have a negative impact of livelihood and food security in general.

\subsubsection{Sodium percentage $(\mathrm{Na} \%)$}

Concentration of sodium in groundwater is important in the classification of irrigation water. $\mathrm{Na} \%$ was calculated using Eq. 3 and results are presented in Table 4. Majority of the groundwater samples in the study area were classified as excellent (3.2\%), good (33.9\%) and permissible (34.7\%) for irrigation purposes. Na\% over 60 can cause destruction of the structures of the soil and negatively affects the growth of plants (6). In the Soutpansberg region, $4.8 \%$ of the samples were doubtful $(\mathrm{Na} \%=60-80)$ and $23.4 \%(\mathrm{Na} \%>80)$ were unsuitable for irrigation purposes. Samples with $\mathrm{Na} \%>80$ contains very low concentration of $\mathrm{Ca}^{2+}(<3 \mathrm{mg} / \mathrm{l})$ and this is hazardous for irrigation water according to (39). Groundwater from the Tshipise geothermal spring is not suitable for irrigation purposes due to low $\mathrm{Ca}^{2+}$ concentration.

\subsubsection{Magnesium hazard (MH)}

Magnesium in groundwater influence the quality of soil by converting it into alkaline and reduces crop yield (19). Magnesium hazard was calculated using Eq. 6 as proposed by (45). MH above 50 is deemed to be unsuitable for irrigation purposes. Groundwater in $75.8 \%$ of the samples was unsuitable for irrigation as $\mathrm{MH}$ was calculated to be over 50 (Table 4). The unsuitability of groundwater based on $\mathrm{MH}$ is a concerning issues as $125.4 \mathrm{Mm} 3 / \mathrm{a}$ has been allocated for irrigation use in the Soutpansberg region. $\mathrm{MH}$ in groundwater was below 50 in $24.2 \%$ the samples of which most of them are from Tshipise (geothermal spring: ZQMTPS2). Samples that are not suitable for irrigation purposes based on $\mathrm{MH}$ is resulting from $\mathrm{Ca}^{2+}>\mathrm{Mg}^{2+}$ ratio. Therefore, groundwater in most part of the Soutpansberg region is not suitable for irrigation purpose based on magnesium hazard. To ensure food security, this information should be shared with the farming community and everyone using groundwater for irrigation purposes. Various digital and media platforms can be used to share the status of groundwater for irrigation uses so precautions can be taken before irrigating.

\subsubsection{Permeability Index (PI)}

Permeability index is based on Eq. 4 and is used to classify irrigation water as proposed by (14). Water from class I $(\mathrm{PI}>75)$ and class II ( $\mathrm{PI} 75-25)$ is considered to be suitable for irrigation while class III is considered to be unsuitable for irrigation. The PI results from the study area are tabulated in Table 4 where $2.4 \%$ of the samples are good (Class I) and $85.5 \%$ of the samples are permissible (Class II) for irrigation purpose. Only $12.1 \%$ of the samples were not suitable (Class III, $\mathrm{PI}<25$ ) resulting from high concentration of $\mathrm{HCO}_{3}{ }^{-}$and relatively low $\mathrm{Ca}^{2+}$ concentration in groundwater is this is hazardous for irrigation water (39).

\subsubsection{Residual sodium carbonate (RSC)}

High concentration of carbonate and bicarbonate ions relative to calcium and magnesium (alkaline earth) can result in the complete precipitation of calcium and magnesium (37). Residual sodium 
carbonate (RSC) calculated using Eq. 5 has been measured in the Soutpansberg region in order to understand the effect of bicarbonate and carbonate of groundwater. High RSC value in water results in an increase of adsorption of sodium in soil (15). Water with RSC less than 2.5 is considered as suitable for irrigation purposes. All 124 groundwater samples were suitable for irrigation purpose as RSC was less than 2.5 (Table 4).

\subsubsection{Total dissolved solids (TDS)}

Suitability of groundwater for irrigation can be determined by using (12) TDS classification (Table 3). Irrigation water with TDS less than $3000 \mathrm{mg} / \mathrm{l}$ is considered suitable/useful for irrigation purposes. TDS concentration levels in groundwater ranged from 32 to $1808 \mathrm{mg} / \mathrm{l}$ which is within the useful for irrigation limit. Therefore, groundwater in the Soutpansberg region is suitable for irrigation based on TDS.

\section{Conclusions}

Groundwater in the Soutpansberg region is slightly acidic to alkaline and classified as fresh to brackish in nature. Concentration levels of parameters such as $\mathrm{F}^{-}, \mathrm{NO}_{3}{ }^{-}, \mathrm{Cl}^{-}$and TDS were high and above the prescribed limit in various areas and villages in the study area. Seasonal variation does not influence the concentration levels of parameters identified as there is no significant difference in both wet and dry season samples. There is correlation between high concentration levels of contaminants such as $\mathrm{NO}_{3}{ }^{-}$ and TDS and human settlements areas. Concentration levels of these contaminants are high in settlements such as Gogogo, Maebane, Nzhelele, Punda Maria and Tshitavha Sambandou where groundwater is not suitable for drinking purposes. Overall groundwater is suitable for drinking purposes in most part of the Soutpansberg region based on physiochemical analysis. Various methods used to determine suitability of groundwater for irrigation purposes gave contrasting results. TDS, Na\%, SAR, PI and RSC determined that groundwater is suitable for irrigation purposes. $\mathrm{MH}$ determined that groundwater is not suitable for irrigation purposes due to low $\mathrm{Ca}^{2+}$ in groundwater. Considering all methods combined, groundwater seems suitable for irrigation purposes in the Soutpansberg region. Presence of contaminants such as $\mathrm{F}^{-}, \mathrm{NO}_{3}{ }^{-}$and salinity in groundwater poses a health risk to the communities using groundwater for drinking purposes without any form of treatment. To ensure food security, improved health and livelihood, this study recommends that the status of groundwater quality in relation to suitability for drinking and irrigation purposes should be shared on digital, print media and if possible to community leaders by researchers and custodians of groundwater. Sharing of information with affected community is important as it will stop the parachute type of research where researchers collect data, analyse and publish without informing affected communities of the hazards associated with groundwater in specific areas. Various Sustainable Development Goals can be accelerated and achieved by sharing research outcomes with water users. There is also a need to develop groundwater quality guidelines for various aquifers to avoid comparing groundwater quality with treated water standards when measuring concentration level between contaminants and pollutants. This study further recommends that there is a need to determine hydro-geochemical influencing groundwater quality in the Soutpansberg region. There is also a need to monitor groundwater for biological parameters in the area 
due to excessive usage of pit-latrines and livestock farming. Consequently, proper management of groundwater and remediation should be considered before utilizing groundwater for drinking purposes.

\section{Declarations}

Acknowledgments: This paper is a part of the Ph.D project of the corresponding author. The authors gratefully acknowledge the Department of Water and Sanitation (DWS) and South Africa Weather Services (SAWS) for assistance with historical data.

\section{Funding: N/A}

Conflicts of Interest: The authors declare no conflict of interest.

Author Contributions: LL was responsible for data collection, data analysis and drafting the manuscript. TK was responsible for conceptualisation of the research problem, interpretation of the results and reviewing of the manuscripts. TK is the academic supervisor of the corresponding author.

Availability of data and material (data transparency): The data used to support the outcomes of this study have been included within the supplementary material.

Code availability (software application or custom code): N/A

\section{References}

1. Adimalla, N. \& Taloor, A.J. 2019. Hydrogeochemical investigation of groundwater quality in the hard rock terrain of South India using Geographic Information System (GIS) and groundwater quality index (GWQI) techniques. Groundwater for Sustainable Development, 10. https://doi.org/10.1016/j.gsd.2019.10028

2. Aladejana, J.A., Kalin, R.M., Sentenac, P. \& Hassan, I. 2020. Assessing the impact of climate change on groundwater quality of the shallow coastal aquifers of Eastern Dahomey Basin, Southwestern Nigeria. Jour. water. 2020, 12, 224. Pp. 1-19. https://doi.org/10.3390/w12010224

3. Badana, N., Vetrimurugan, E. \& Natarajan, R. 2018. Coastal aquifer contamination and geochemical processes evaluation in Tugela catchment, South Africa-geochemical and statistical approaches. Water 10(6): 687. https://doi.org/10.3390/w10060687

4. Barker, O.B. 1983. A proposed geotectonic model for the Soutpansberg Group within the Limpopo Mobile Belt, South Africa. Special Publication geological Society South Africa. 8: 181-190.

5. Barton Jr, J.M. \& Pretorius, W. 1997. Soutpansberg age (1.85 Ga) magmatism and metallogenesis in southern Africa: a result of regional rifting. Abstract: International Symposium on plumes, plates and mineralisation. University of Pretoria, Pretoria, South Africa.

6. Bhat, M.A., Wani, A.S., Vijay, K., Jyotirmaya, S. \& Dinesh, T. 2018. An overview of the assessment of groundwater quality for irrigation. J. Agric. Sci. Food. Res. 9: 209. 
7. Brandl, G. 1987. The geology of the Tzaneen area. Explanation sheet geological Survey South Africa. 2330: 55.

8. Brandl, G. 1999. Soutpansberg Group: Catalogue of South African Lithostratigraphic units. SA Committee for stratigraphy. Council for Geoscience. 6: 39-41.

9. Brhane, G.K. 2018. Characterization of hydro chemistry and groundwater quality evaluation for drinking purpose in Adigrat area, Tigray, Northern Ethiopia. Water Science 32 (2018): 213-229.

10. Chande, M.M. \& Mayo, A.W. 2019. Assessment of groundwater vulnerability and water quality of Ngwerere sub-catchment urban aquifer in Lusaka, Zambia. Physics and Chemistry of the Earth. 112: 113-124. https://doi.org/10.1016/j.pce.2019.03.004

11. Cheney, E.S., Barton, J.M. \& Brandl, G. 1990. Extent and age of the Soutpansberg sequences of southern Africa. South African Journal of Geology. 93: 664-675.

12. Davis, S.N. \& DeWiest, R.J. 1966. Hydrogeology. Wiley, New York.

13. Deshpande, S.M. \& Aher, K.R. 2012. Evaluation of groundwater quality and its suitability for drinking and agriculture use in parts of Vaijapur, District Aurangabad, MS, India. Res. J. Chem. Sci. 2(1): 2531.

14. Doneen, L.D. 1964. Water quality for agriculture. Department of irrigation, University of Carlifonia.

15. Eaton, F.M. 1950. Significance of Carbonates in irrigation waters. Soil Science. 69 (2): 123-134.

16. Egbueri, J.C. 2020. Groundwater quality assessment using pollution index of groundwater (PIG), ecological risk index (ERI) and hierarchical cluster analysis (HCA): a case study. Groundwater for Sustainable Development. 10 (100292).

17. Eyinla, D.S. and Oladunjoye, M. A. 2014. Improving quality agricultural practices in tropical environments through integrated geophysical methods. IOSR. J. Appl. Geol. Geophys (IOSR-JAGG). 2(5): 128-139.

18. Freeze, R.A. and Cherry, J.A. 1979. Groundwater. Prentice-Hall, Englewood cliffs.

19. Gowd, S.S. 2005. Assessment of groundwater quality for drinking and irrigation purpose: a case study of Pedavanka Watershed. Anantapur District, Andhra Pradesh, India. Environmental Geology. 48: 702-712.

20. He, X., Li, P., Ji, Y., Wang, Y., Su, Z. \& Elumalai, V. 2020. Groundwater arsenic and fluoride and associated arsenicosis and fluorosis in China: occurrence, distribution and management. Expo Health. https://doi.org/10.1007/s12403-020-00347-8

21. Hussain, M. \& Rao, D.P. 2013. Assessment of the ground water quality and its suitability for drinking and irrigation purposes: a case study of Patancheru, Andhra Pradesh, India. Arch. Appl. Sci. Res. 5(6): 232-238.

22. Hwang, J.Y., Park, S., Kim, H.K., Kim, M.S., Jo, H.J., Kim, J.I., Lee, G.M., Shin, I.K. \& Kim, T.S. 2017. Hydrochemistry for the assessment of groundwater quality in Korea. J. Agric. Chem. Environ. 6: 1-29. https://doi.org/10.4236/jacen.2017.61001 
23. Jackson, R.B., Carpenter, S.R., Dahm, C.N., McKnight, D.M., Naiman, R.J., Postel, S.L., \& Running, S.W. 2001. Water in changing world, issues in Ecology. Ecol. Soc. Am, Washington, 1-16.

24. Jalees, M.I., Farooq, M.U. \& Anis, M. 2020. Hydrochemistry modelling: evaluation of groundwater quality deterioration due to anthropogenic activities in Lahore, Pakistan. Environ. Dev. Sustain (2020).

25. Kokkat, A., Jegathambal, P. \& James, E.J. 2016. Spatial and temporal variation in groundwater quality and impact on sea water in the Cauvery delta, South India. Int. J. Earth. Sci. 9(3): 383-392.

26. Li, P., Wu, J. \& Qian, H. 2016. Hydrochemical appraisal of groundwater quality for drinking and irrigation purposes and the major influence factors: a case study in and around Hua County, China. Arab. J. Geosci. 9(1): 15. https://doi.org/10.1007/s12517-015-2059-1

27. Li, P., He, S., Yang, N. \& Xiang, G. 2018. Groundwater quality assessment for domestic and agricultural purposes in Yan'an City, northwest China: Implications to sustainable groundwater management on the Loess Plateau. Environ. Earth. Sci. 77 (23): 775. https://doi.org/10.1007/s12665-018-7968-3

28. Malaza, N. 2017. Hydrogeochemical assessment of groundwater quality in the Soutpansberg basin around Tshikondeni, Limpopo Province, South Africa. Geochemistry: Exploration, Environment, Analysis, 17(1): 35-41. https://doi.org/10.1144/geochem2016-433

29. Mangoua, M.J., Gone, D.L., Kouassi, K.A., N’guettia, K.G., Douagui, G.A., Savane, I. \& Biemi, J. 2015. Hydrogeochmical assessment of groundwater quality in the Baya watershed (Eastern of Cote d'Ivoire). Afri. J. Agric. Res. Vol.10 (49): 4477-4489. https://doi:10.5897/AJAR2015.10212

30. Meride, Y., \& Ayenew, B. 2016. Drinking water quality assessment and its effects on residents health in Wondo genet campus, Ethiopia. Environ. Syst. Res, Vol. 5:1. https://doi:10.1186/s40068-016-00536

31. Mokoena, P., Kanyerere, T. \& van Bever Donker, J. 2020. Hydrogeochemical characteristics and evaluation of groundwater quality for domestic and irrigation purposes: a case study of the Heuningnes Catchment, Western Cape Province, South Africa. Applied. Sci. (2020) 2: 1548. https://doi.org/10.1007/s42452-020-03339-0

32. Napacho, A., \& Manyele, V. 2010. Quality assessment of drinking water in Temeke district (Part II): characterization of chemical parameters. Af. J. Environ. Sci. Technol, Vol. 4 (11): 775-789.

33. Odiyo, J.O., and Makungo, R. 2012. Fluoride concentrations in groundwater and impact on human health in Siloam Village, Limpopo Province, South Africa. Water SA, Vol. 38 (5): 731-736. https://dx.doi.org//0.4314/wsa.v38i5.12

34. Odiyo, J.O., Makungo, R., and Muhlari, T.G. 2014. The impacts of geochemistry and agricultural activities on groundwater quality in the Soutpansberg fractured aquifer. WIT Transaction on Ecology and The Environment, Vol 182: 121-132. https://doi:10.2495/WP140111

35. Papazotos, P., Koumantakis, I., \& Vasileiou, E. 2019. Hydrogeochemical assessment and suitability of groundwater in a typical Mediterranean coastal area: a case study of the Marathon basin, NE Attica, Greece. Hydro Research. 2: 49-59. https://doi.org/10.1016/j.hydres.2019.11.002 
36. Prasanna, M.v., Chidambaram, S., Gireesh, T.V., Jabir Ali, T.V. 2010. A study on hydrochemical characteristics of surface and subsurface water in and around Perumal Lake, Cuddalore District, Tamilnadu, South India. Environ. Earth. Sci. https://doi.org/10.1007/s12665-010-0664-6

37. Raghunath, H.M. 2000. Ground Water Hydrology. Wiley Eastern Ltd. Second reprint.

38. Raheli-Namin, S., Mortazavi, M., Mobinifar, M.A. 2016. Groundwater quality probability mapping and assessment for domestic and irrigation purposes in Ghara-Su Basin of Golestan Province, Iran. J. Mater. Environ. Sci. 7 (1): 259-271.

39. Richards, L.A. 1954. Diagnosis and improvement of saline and alkali soils. US Department of Agriculture, Hand Book 60.

40. SABS (South African Bureau of Standards). 2015. South African National Standard 241-1: 2015 Drinking water, Part 1: Microbiological, Physical, aesthetic and chemical determinands. 241-2: 2015 drinking water, Part 2: Application of SANS 241-1. SABS, Pretoria.

41. Sasikaram, S., Sritharan, K., Balakumar, S., \& Arasaratnam, V. 2012. Physical, chemical and microbial analysis of bottled drinking water. J. Ceylon Medical, 57 (3), 775-789.

42. Sefie, A., Aris, A.A., Shamsuddin, M.K.Z., Tawnie, I., Suratman, S., Idris, A.N., Saadudin, B.S., and Ahmad, W.K. 2015. Hydrogeochemistry of groundwater from different aquifer in Lower Kelantan Basin, Kelantan, Malaysia. Proced. Environ. Sci. 30: 151-156.

43. Selvakumar, S., Chandrasekar, N., and Kumar, G. 2017. Hydrogeochemical characteristics and groundwater contamination in the rapid urban development areas of Combatore, India. Water resources and urban industry journal, 17 (2017) 26-33.

44. Stengel, D.B., O'Reilly, S., and O'Halloran, J. 2006. In Davenport, J., and Davenport, J.L (eds). The Ecology of Transportation: Managing mobility for the Environment. Environmental Pollution, Vol 10. Springer, Dordrecht. https://doi.org/10.1007/1-4020-4504-2_15

45. Szaboles, I. and Darab, C. 1964. The influence of irrigation water of high sodium carbonate content of soils. Proceedings of $8^{\text {th }}$ ISSS, Transaction. 2: 802-812.

46. Taiwo, A.M., Towolawi, A.T., Olanigan, A.A., Olujimi, O.O., and Arowolo, T.A. 2015. Comparative assessment of groundwater quality in rural and urban areas of Nigeria. Research and Practices in Water Quality: 179-191. https://dx.doi.org/10.5772/59669

47. Thorne, D.W. \& Peterson, H.B. 1954. Irrigated Soils. Constable and Company, London, UK.

48. Weaver, J.M.C., Cave, L. \& Talma, A.S. 2007. Groundwater sampling, $2^{\text {nd }}$ edn. WRC Report No. TT303/07. Water Research Commission, Pretoria.

49. Weight, W.D. 2008. Hydrogeology field manual, $2^{\text {nd }}$ edn. McGraw-Hill Companies Inc, New York. 50. WHO. 1997. Basic Environmental Health, Geneva.

51. WHO. 2011. Guidelines or Drinking-water quality. $4^{\text {th }}$ edition, World Health Organization, Geneva.

52. Wu, J., Wang, L., Wang, S., Tian, R., Xue, C., Feng, W., Li, Y. 2017. Spatiotemporal variation of groundwater quality in an arid area experiencing long-term paper wastewater irrigation, northwest China. Environ. Earth. Sci. 76(13): 460. https://doi.org/10.1007/s12665-017-6787-2 
53. Wu, J., Zhou, H., He, S., Zhong, Y. 2019. Comprehensive understanding of groundwater quality for domestic and agricultural purposes in terms of health risks in a coal mine area of the Ordos basin, north of the Chinese Loess Plateau. Earth. Sci. 78(15): 446. https://doi.org/10.1007/s12665-019$8471-1$

\section{Figures}

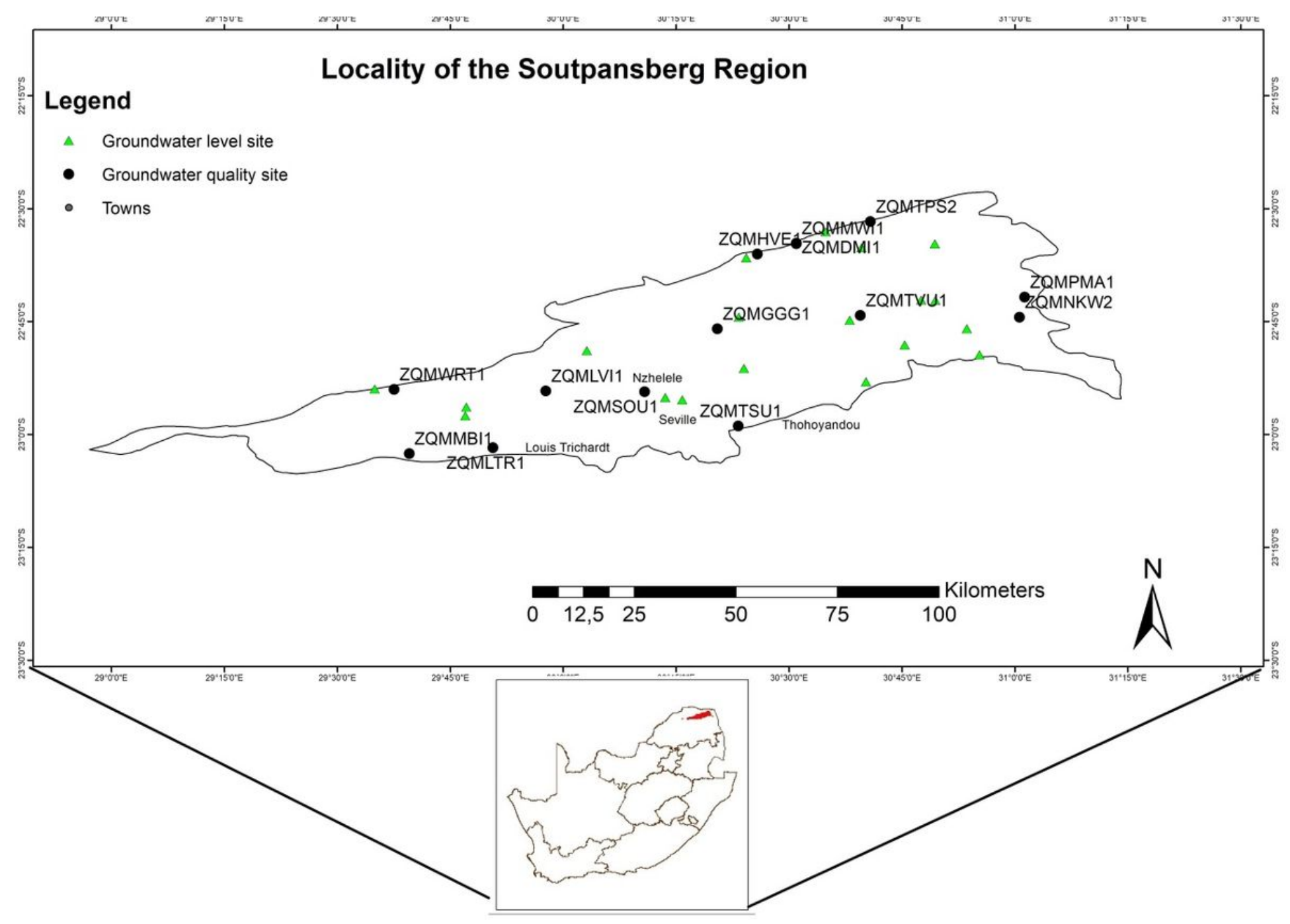

Figure 1

Locality map of the Soutpansberg region with existing groundwater monitoring stations Note: The designations employed and the presentation of the material on this map do not imply the expression of any opinion whatsoever on the part of Research Square concerning the legal status of any country, territory, city or area or of its authorities, or concerning the delimitation of its frontiers or boundaries. This map has been provided by the authors. 


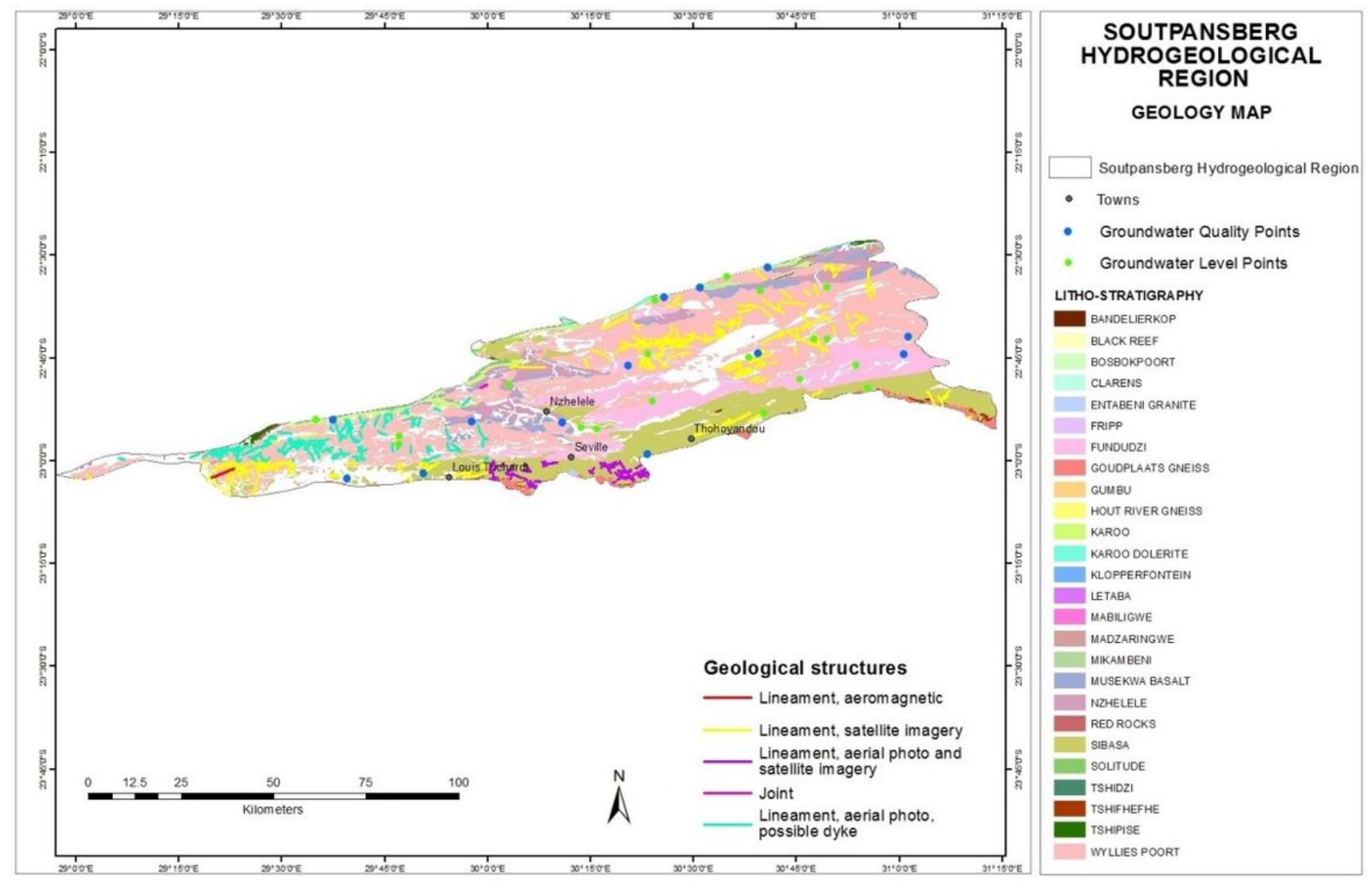

Figure 2

Geological settings of the Soutpansberg region Note: The designations employed and the presentation of the material on this map do not imply the expression of any opinion whatsoever on the part of Research Square concerning the legal status of any country, territory, city or area or of its authorities, or concerning the delimitation of its frontiers or boundaries. This map has been provided by the authors. 


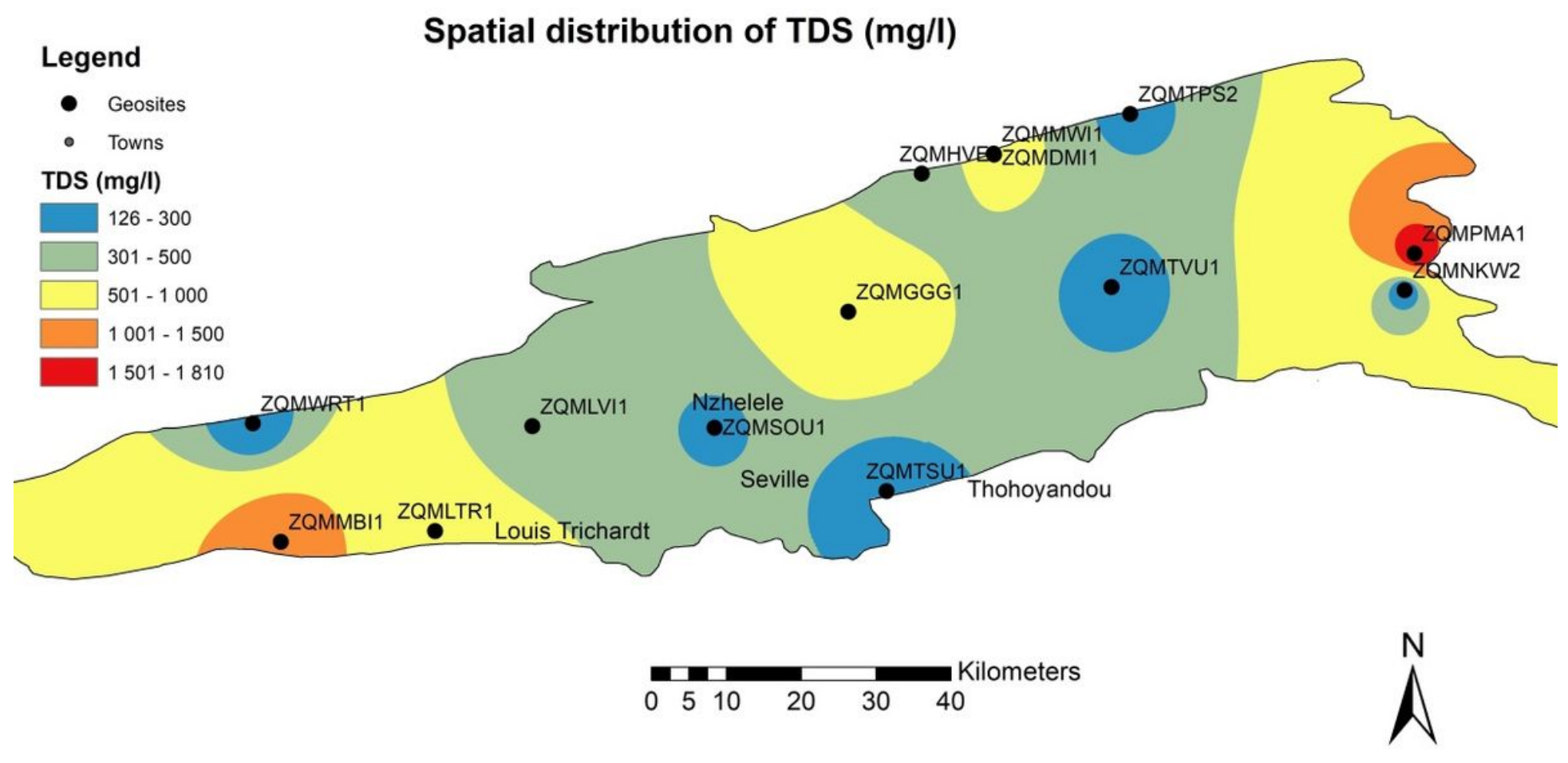

Figure 3

Spatial distribution of TDS in the Soutpansberg region Note: The designations employed and the presentation of the material on this map do not imply the expression of any opinion whatsoever on the part of Research Square concerning the legal status of any country, territory, city or area or of its authorities, or concerning the delimitation of its frontiers or boundaries. This map has been provided by the authors.

\section{Legend}
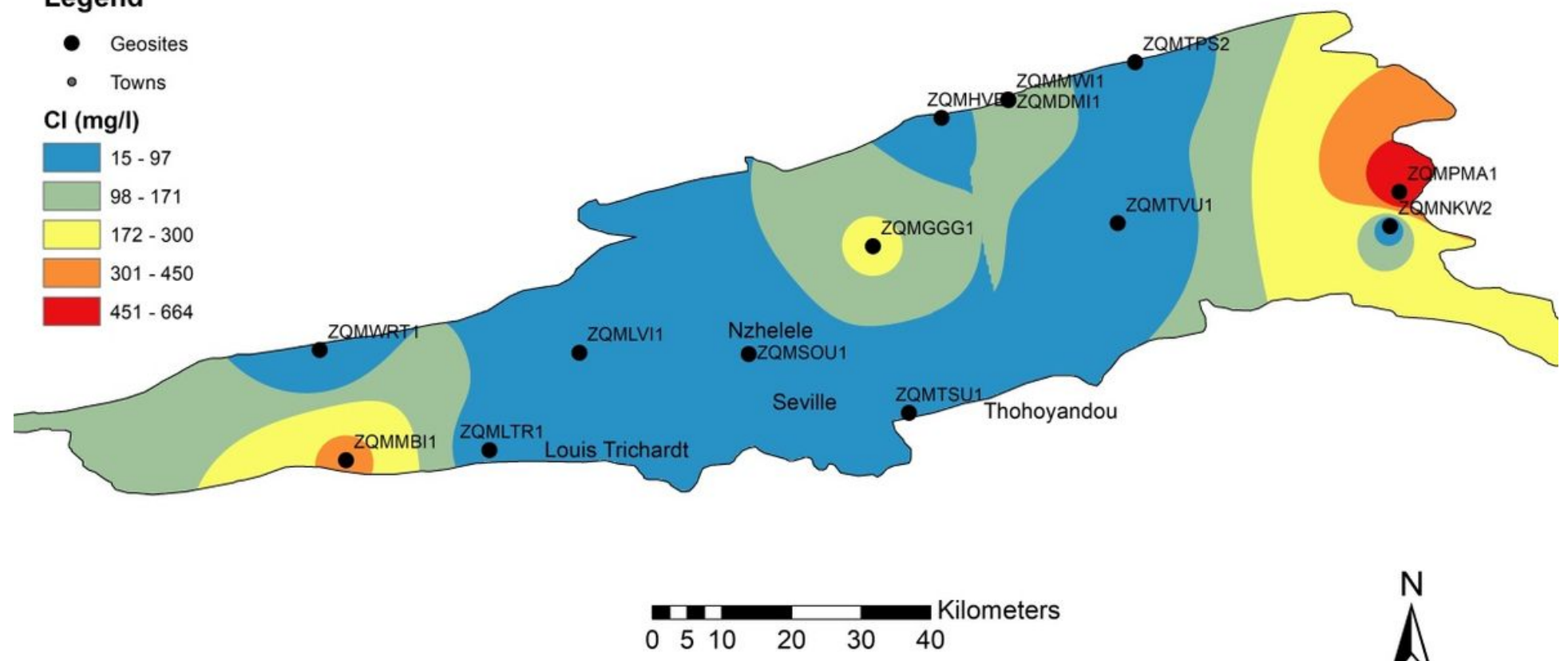
Spatial distribution of Chloride in the Soutpansberg region Note: The designations employed and the presentation of the material on this map do not imply the expression of any opinion whatsoever on the part of Research Square concerning the legal status of any country, territory, city or area or of its authorities, or concerning the delimitation of its frontiers or boundaries. This map has been provided by the authors.

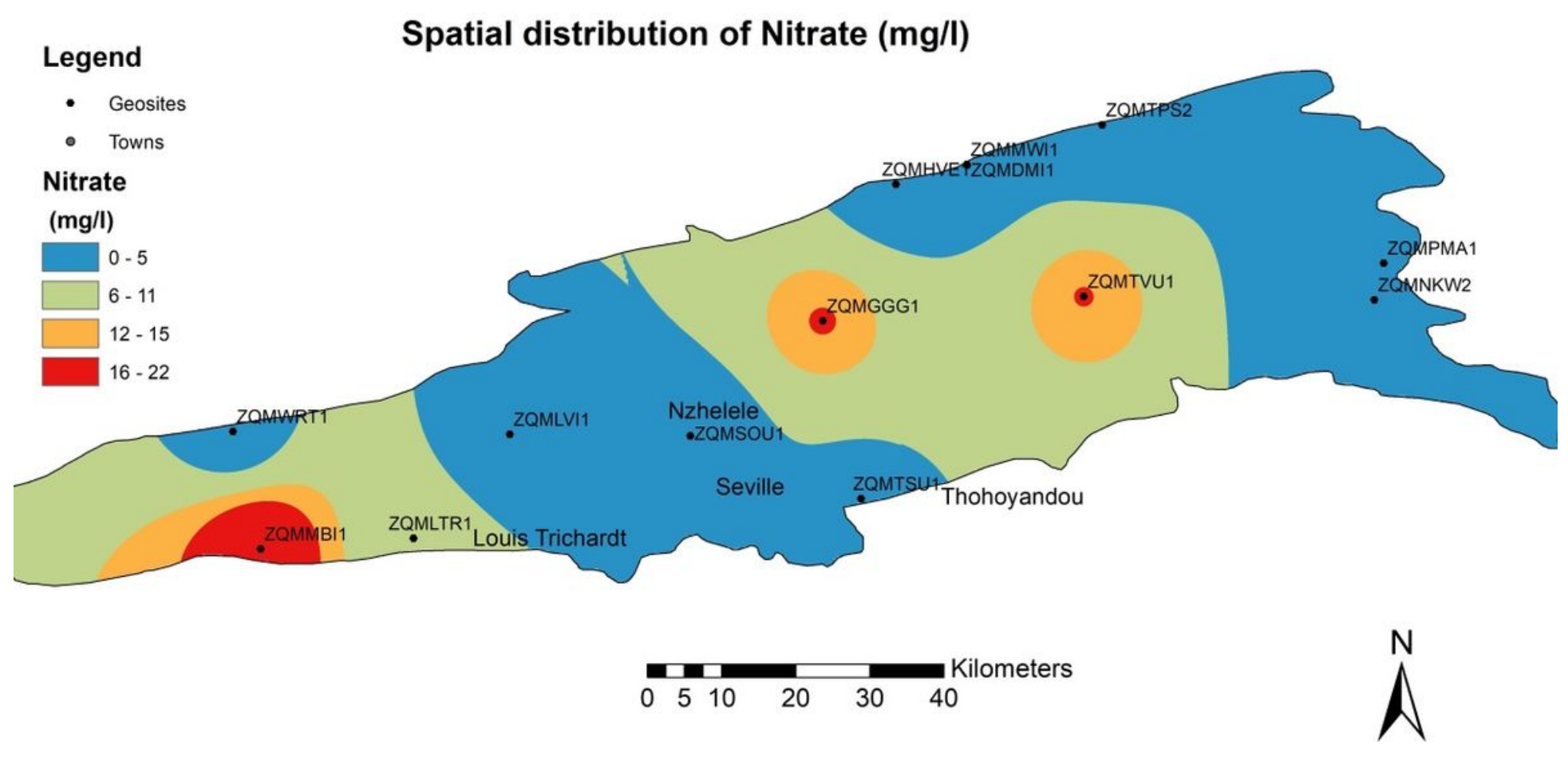

Figure 5

Spatial distribution of Nitrate in the Soutpansberg region Note: The designations employed and the presentation of the material on this map do not imply the expression of any opinion whatsoever on the part of Research Square concerning the legal status of any country, territory, city or area or of its authorities, or concerning the delimitation of its frontiers or boundaries. This map has been provided by the authors. 


\section{Spatial distribution of Fluoride ( $\mathrm{mg} / \mathrm{l})$}

- Geosites

- Towns

Fluoride (mg/l)

$<$ VALUE>
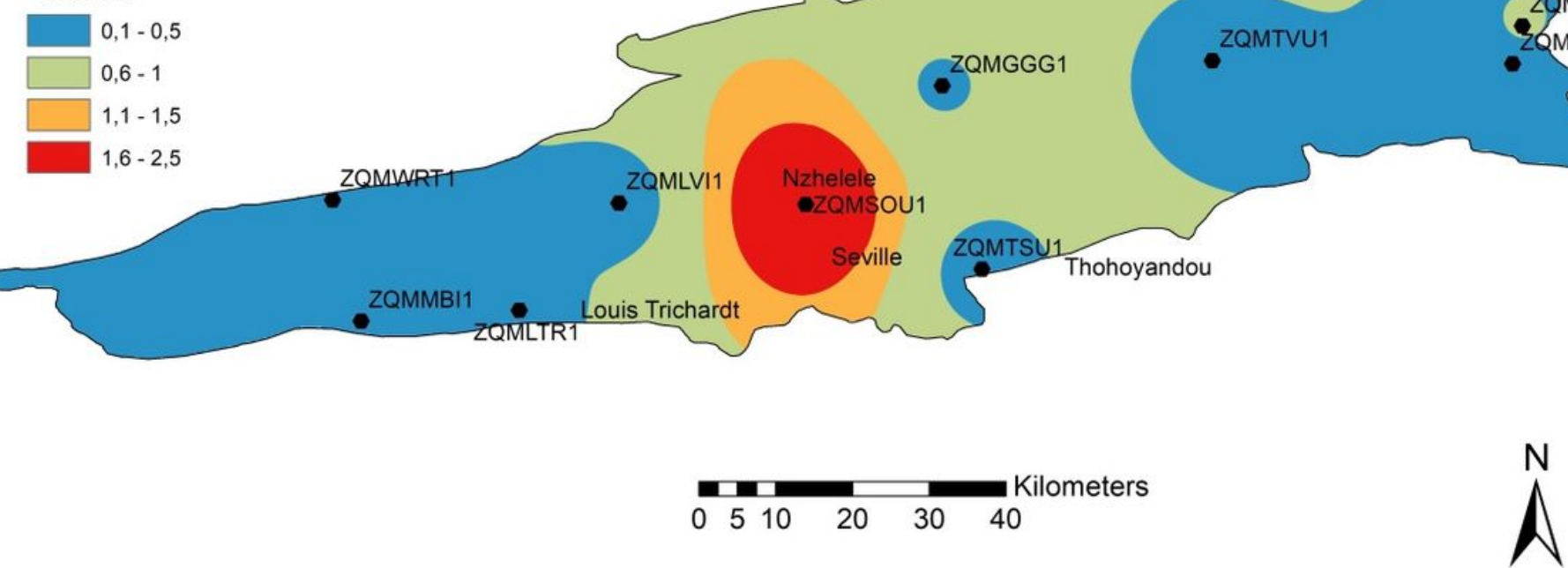

\section{Figure 6}

Spatial distribution of Fluoride in the Soutpansberg region Note: The designations employed and the presentation of the material on this map do not imply the expression of any opinion whatsoever on the part of Research Square concerning the legal status of any country, territory, city or area or of its authorities, or concerning the delimitation of its frontiers or boundaries. This map has been provided by the authors.

\section{Spatial distribution of $\mathrm{Mg}(\mathrm{mg} / \mathrm{l})$}
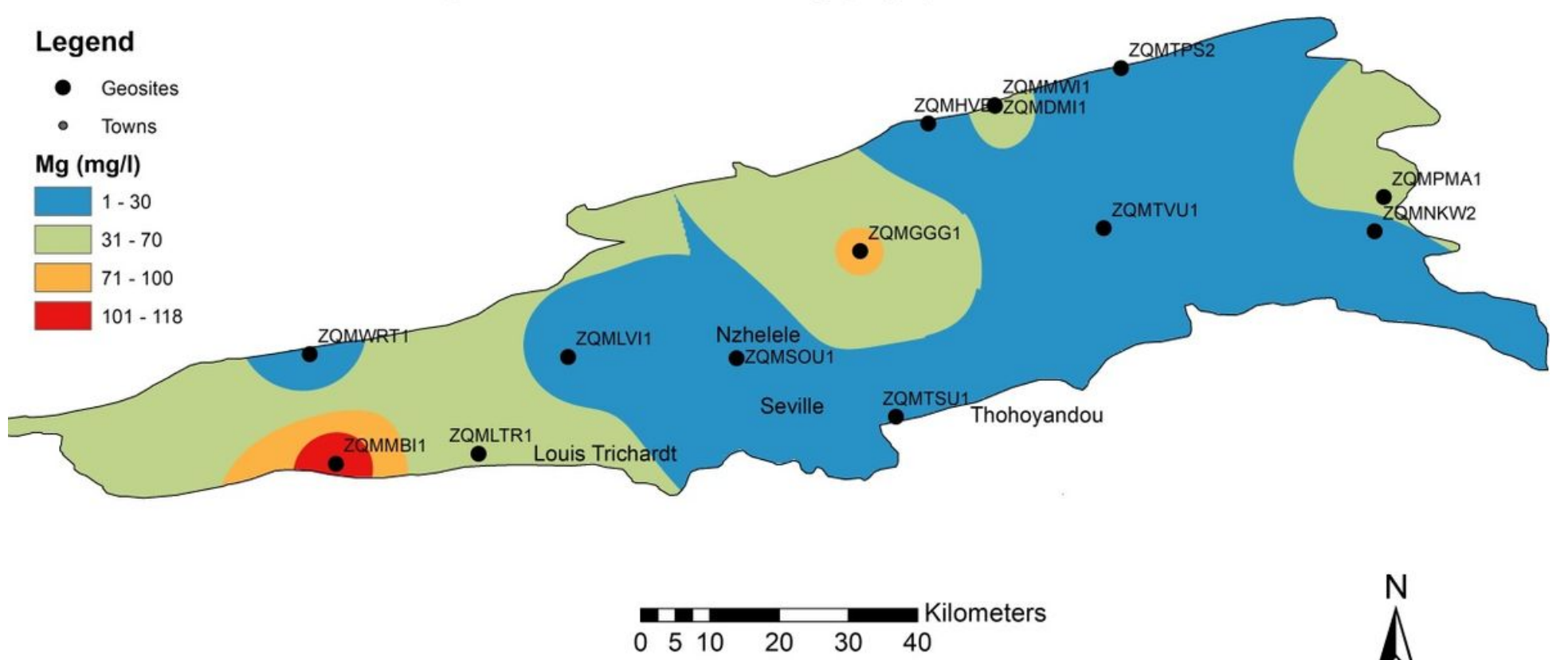
Spatial distribution of Magnesium in the Soutpansberg region Note: The designations employed and the presentation of the material on this map do not imply the expression of any opinion whatsoever on the part of Research Square concerning the legal status of any country, territory, city or area or of its authorities, or concerning the delimitation of its frontiers or boundaries. This map has been provided by the authors.

\section{Spatial distribution of SAR (meq/l)}

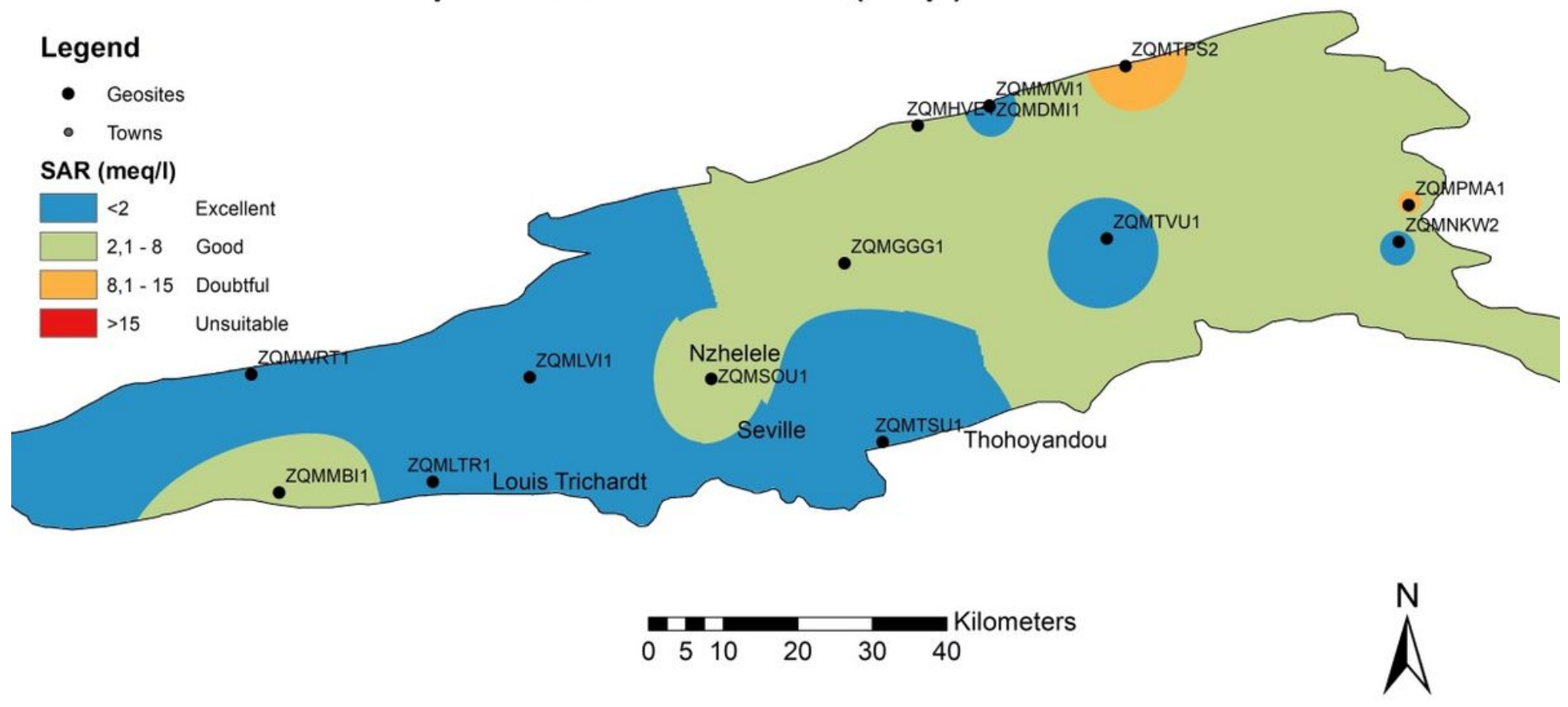

Figure 8

Spatial distribution of suitability of groundwater for irrigation based on SAR Note: The designations employed and the presentation of the material on this map do not imply the expression of any opinion whatsoever on the part of Research Square concerning the legal status of any country, territory, city or area or of its authorities, or concerning the delimitation of its frontiers or boundaries. This map has been provided by the authors.

\section{Supplementary Files}

This is a list of supplementary files associated with this preprint. Click to download.

- Rawgroundwaterqualitydata.xlsx 